\title{
International environmental justice and the quest for a green global economy: introduction to special issue
}

\author{
Chukwumerije Okereke • Timothy G. Ehresman
}

Received: 2 September 2013/Accepted: 20 October 2014/Published online: 2 November 2014

(C) Springer Science+Business Media Dordrecht 2014

\section{Introduction}

"Green economy" has gathered significant attention as a guiding principle and/or aspiration for organizing national and global economic activity. The popularity of the concept soared when it was adopted as a key organizing theme for the 20th anniversary of the United Nations Conference on Environment and Development (Rio +20$)$ in Brazil, June 2012. Since then it has remained a growing focus of global environmental politics scholarship as well as various institutions for international environmental governance such as the UN Environment Programme (UNEP), the International Labour Organization (ILO) and the UN Industrial Development Organization (UNIDO), all of which have recently come together to set up a new partnership for action on green economy.

A clear and dominant definition of "green economy" is yet to emerge, but the central ideas appear to include resource efficiency, decoupling economic growth from environmental externalities and the notion of producing more with less (Barbier 2012; Clapp and Dauvergne 2011; Desombre 2011; Godoy 2012; UNEP 2011).

One of the central questions that has emerged as scholars and policy makers around the world explore possible new patterns of development through the prism of the green economy concerns its relationship with environmental justice (Swilling and Annecke 2012; Newell and Mulvaney 2013). Does green economy facilitate a deeper or shallower engagement with social and environmental justice? Would the pursuit of national and global economic growth on the platform of the green economy secure a fairer process and

C. Okereke (ه)

Department of Geography and Environmental Science, University of Reading, Whiteknights Campus, P.O. Box 433, Reading RG6 6AB, UK

e-mail: c.okereke@ reading.ac.uk

T. G. Ehresman

Department of Politics, University of the South-Sewanee, Sewanee, TN 37383, USA

e-mail: tgehresm@sewanee.edu 
outcome for those who disproportionately bear the burden of environmental impacts associated with economic development?

Over the last three decades, scholars interested in the ethical dimensions of global governance have explored the relationship between sustainable development and social/ environmental justice in both theory and practice (e.g., Stadelman et al. 2014: Nielsen 2014; Rao 2014). From the analysis of its local origin in the "political contestation of proposals to site polluting and toxic facilities in predominantly poor and black communities in the US" (Walker and Bulkeley 2006: 655) to works focusing on its broader and global dimensions, two key insights stand out.

The first is that while the concepts of sustainable development and social justice are closely intertwined, the two objectives are not always, in practice, attainable simultaneously (Beckerman 1994; Daly 1995; Dobson 1998; Ehresman and Stevis 2011; Jacobs 1999; Langhelle 2000; Redclift 2002). The second is that while the notion of sustainable development has engendered a proliferation of justice concerns at both national and international scales, these articulations have not so far proved sufficiently momentous to materially alter prevailing global economic structures and ideas firmly rooted in neoliberal prescriptions for free-market capitalism (McKendry and Janos 2015; Bratman 2015; Benton 1999; Bernstein 2001; Jamieson 2007, Newell 2005; Okereke 2008, 2011; Paterson et al. 2003; Sachs 1999).

The question then is: What does the increasing emphasis on green economy imply for (social) equity, justice and environmental sustainability? Does the green economy serve to deepen links between economic growth and environmental justice compared to precursor concepts such as sustainable development (Ehresman and Okereke 2015)?

The above questions imply the recognition: (a) of both the positive relationship and the abiding tensions between economic development and social-environmental justice (Stevis and Felli 2015); and (b) that the new quest for a green economy could portend either greater synergy or more tension between justice and economic growth (McKendry and Janos 2015).

Already, a variety of lines are discernible from emergent literature and policy debates. UNEP, for example, contends that the green economy is not a replacement for but rather a means of achieving sustainable development. The body is positive that the Green Economy Initiative "is not generally a drag on growth but a new engine for growth .... and a vital strategy for eliminating persistent poverty and increasing social equity" (UNEP 2011: 2). Others (e.g., Bowen and Fankhauser 2011) suggest that the concept implies "a paradigm shift." Green economy, they say, calls for "deep, structural and systemic" changes in the economy as opposed to the tinkering at the margins with which extant literature on sustainability is associated (p. 1158; see also Stevis and Felli 2015).

However, many in developed but especially developing countries are not convinced. These are concerned that "green economy" is yet another pretext for green protectionism which they feel will hinder economic development and exacerbate national and global inequality. They prefer that the emphasis continues to be on the sustainable development with its explicit conceptual links to poverty eradication, social justice and environmental protection.

Others worry that the green growth initiative is nothing but a ruse which will lead to more tax by governments, especially on fossil fuels and other products deemed to be less ecologically benign (Bernstein 2013; Brockington 2012; Evanoff 2011; Kosoy et al. 2012).

There may well be elements of truth in all of these positions but what is indisputable is that, at least in the short term, there will be winners and losers in transitions to a greener technology and economy (DeSombre 2011: 469). Furthermore, the move to a green 
economy would itself entail material costs, and green products and services may generate their own externalities and risks. For example, "green" jobs in solar photovoltaic (PV) and long-lived lithium battery manufacturing may involve exposures to harmful materials or generate hazardous wastes which may end up in the backyard of poor and vulnerable communities (Coyle 2011; Mulvaney 2009).

There is the need, therefore, to carefully consider if, where and how policies aimed at encouraging a greener economy can better take account of the full range of justice impacts and prospects such a transition would generate. These are the questions to which this special issue is dedicated.

The idea for the special issue has its origin in two International Studies Association (ISA) panels on "International Political Economy and Environmental Justice" convened by the co-editors in 2012. We invited papers that interrogated the conceptual and practical relationship between sustainable development, green economy and social-environmental justice. What, if any, is the difference between sustainable development and green economy and how do these concepts implicate questions of justice at national and international scales? What are the lessons, from justice and equity perspectives, that can be learnt from the 30 years of effort at the pursuit of sustainable development-both at local and national levels - and how may these lessons be applied in the quest for the transition to a new green economy? What evidence of tensions and questions of justice are already arising from the jurisdictions and sectors that purport to be or are seriously implementing policies to promote a green economy? What are the opportunities for achieving greater distributional justice in the transition toward a green economy and how might relevant stakeholders best exploit such opportunities?

The papers we selected for the special issue reflect our intention to broaden the debate and open the door for critical exploration of the justice implications as well as the tensions, synergies and trade-offs implicated in the new quest for a green global economy.

\section{Roadmap to the special issue}

Each contribution contained herein notes in some respect a tension between social justice and green economic moves, at least in the present global neoliberal paradigm. The recognition of the potential disconnect between justice and green economy is in each case founded on a considered analysis of a particular empirical or analytical context, as providing a concrete basis upon which to suggest that there is more to be done to effectively accommodate the needs of those who stand to lose in the course of, or in spite of, a greener economy.

"Environmental Justice and Conceptions of the Green Economy" by Ehresman and Okereke (2015) is a review article which offers several typologies for categorizing various conceptions of the green economy and interpretations of environmental justice, which then provide a broader framework for the articles which follow. Their first typology differentiates green economy on the basis of its transformative potential and the second differentiates according to its perceived relationship to sustainable development. The third is the most original and most elaborate. It differentiates between three conceptions of green economy on the basis of multiple criteria including primarily implications for international economic structure, social justice, political institutions and concomitant public policy.

More particularly, on the first schema, they suggest green economy can be categorized as having (a) a radical transformative potential, (b) very little transformative potential and (c) no transformative effect. In terms of the relationship with sustainable development, 
they suggest that there are again three possible interpretations: The one where green economy is perceived as displacing sustainable development, the other where green economy is seen as facilitating sustainable development and the third where both concepts are seen as coextensive. Innovatively, Ehresman and Okereke (2015) also provide an extensive review in which they offer a systemization of possible interpretations of green economy mapped onto a synthesis of existing typologies of environmental justice. Their survey has produced the following categories: (1) Thin Green Economy/Market Justice; (2) Moderate Green Economy/Egalitarian Justice and (3) Thick Green Economy/Structural Justice. The conclusion they draw is that green economy does not resolve, but rather reinvigorates existing debates over the visions, actors and policies best suited to secure a more sustainable future for all. It is hoped that this classification will provide the context for future analysis of which, and how, various notions of green economy link with various conceptions of justice.

In keeping with these thematic observations, in "Global Labor Unions and Just Transition to a Green Economy," Stevis and Felli (2015) assess the contribution of global labor unions to understanding how a transition toward a more green economy implicates issues of justice and the varieties of approaches that can be detected. The context of their contribution is the observation that while global labor unions had been among the most articulate in analyzing the social justice implications of "just transition" strategies broadly, the unions have been less vocal about the notions and implications of the new green economy global transformation agenda.

Based on a framework that combines various ideas of environmental justice, political economy and political ecology, Stevis and Felli (2015) isolate three main "visions" of green economy transitions prevalent among global labor unions. The first is a "shared solution" approach which emphasizes commonality among the employers and the employed with stress on dialog as the means of constructing the goals and process tools for achieving green economy transition. The second is the "differentiated responsibility approach" where attention is more on what divides than what unites. The differentiated responsibly approach is far more sensitive to the configurations of power among relevant actors and the need for affirmative action to achieve greater fairness in the transition process. A core strategy is promoting more voice for workers. Here, there is a greater recognition that the green economy transition will entail some winners and losers. Accordingly, considerable effort is devoted to defending the rights and interests of those that will lose out in the transition process. The last category according to Stevis and Felli (2015) is the "social ecological" approach which pushes for far more radical changes in social and economic power structures as a precondition to just green transition.

Crucially and innovatively, Stevis and Felli (2015) find that there are strong correlations between union sectors and dominant visions of just green transition with, for example, the differentiated interest and responsibility view dominating in sectors "whose growth (and even existence) may be negatively affected by environmental regulations, such as chemicals, mining and manufacturing." This suggests the possibility of deeper fractures and fault lines emerging among the labor unions as the transition process intensifies.

Interestingly, the paper from Bratman (2015) shows that in fact fractures and division among hitherto homogenous social and activist groups are already quite common in national contexts where practical attempts are being made to negotiate and implement green economy policies. In "Passive Revolution in the Green Economy: Activism and the Belo Monte Dam," Bratman (2015) traces the development of opposition to the Belo Monte Dam currently under construction in the eastern Brazilian Amazon as a means of offering an "on-the-ground" assessment of the compatibility of environmental justice 
concerns with a state-level focus on green economy and development. Highlighting the dominance of neoliberal economic ideology, Bratman (2015) demonstrates the challenges confronting both states and activist groups as they seek to negotiate and resolve the tensions and trade-offs implicated in green economy transition.

Relying on extensive field research and numerous interviews with parties on both sides of the issue, the article outlines the hegemony of neoliberal state-led iterations of green economy. Employing Gramscian insights on power, hegemony, passive revolution and wars of position, the paper shows that the green economy can be used as a hegemonic tool of technocratic governance and global capitalism. It also details the moves that the historic bloc frequently deploy to cause friction, isolate and weaken social justice and environmental activist alliances campaigning for radical visions of green economy transition.

In its conclusion, the article notes that the green economy discourse is actually driving new configurations and associations within and among state and civil society, leaving those opposed to green economy with few real options. Indeed, the author suggests that the development and reinforcement of a greater hegemony by the state and governing elites may be one of the most notable developments of a move toward a greener economy in Brazil, and beyond.

In "Greening the Industrial City: Equity, Environment, and Economic Growth in Seattle and Chicago," McKendry and Janos (2015) employ qualitative and anthropological research approaches to further identify the tensions and trade-offs implicated in the transition to green economy, in this case with regard to in urban cities in the USA. Focusing deliberately on more marginalized areas of each city, the authors ask whether the greening of sites for potential economic activity, and efforts to attract new investment capital oriented toward greener projects, can be effectively implemented without the displacement and often inequitable impacts generated by urban gentrification.

Mining data from a wide variety of sources and drawing from the literature on neoliberal urbanism, McKendry and Janos (2015) show that while the sense of antagonism and variegated interests may be more muted in the developed North than the developing South, there are nevertheless deep and abiding tensions implicated in the bid by many city leaders in the global North to use greening as a way to compete in the globalized economy.

Interestingly, the paper shows that the main critical difference that determines how, and the extent to which, these tensions are resolved (or not) is the quality of participation and procedural justice built into the transition process. Cities that facilitate genuine participation from a broad spectrum of stakeholders are far more likely to douse tension and achieve progress than those that seek to push through with other visions. Nevertheless, the authors remain skeptical about the prospects of participation, no matter how genuine and far reaching, to result in urban greening approaches that truly undermine prevailing neoliberal approaches. These are insights into participation in green transition in the North that can help governments and activists in the South navigate the process of urban greening in less acrimonious if imperfect ways.

\section{Summing up and looking ahead}

This is only a start, and hopefully a useful foundational exploration, in a research field that promises to dominate the landscape in the years to come. What is clear is that the invocation of "green economy" does not necessarily resolve the tension between economic growth and activity on the one hand, and environmental sustainability and justice on the other. Although those normatively committed to greater environmental justice would have 
wished otherwise, it is clear that in actual practice, a greener economy will not necessarily ensure that social and environmental justice concerns are sufficiently taken up. What is needed is greater intellectual awareness about the opportunities for justice that exist and how these may be exploited. At the same time, it is important to be aware that, without adequate attention, it is entirely possible that the green economy can in fact become a legitimating discourse that provides cover for muting alternative voices and visions for just green transition across different geographies.

\section{References}

Barbier, E. B. (2012). The green economy post Rio + 20. Science, 338, 887-888.

Beckerman, W. (1994). Sustainable development: Is it a useful concept? Environmental Values, 3(3), $191-210$.

Benton, T. (1999). Sustainable development and the accumulation of capital: Reconciling the irreconcilable? In A. Dobson (Ed.), Fairness and futurity: Essays on environmental sustainability and social justice. Oxford: Oxford University Press.

Bernstein, S. (2001). The compromise of liberal environmentalism. New York: Columbia University Press.

Bernstein, S. (2013). Rio + 20: Sustainable development in a time of multilateral decline. Global Environmental Politics, 13(4), 12-21.

Bowen, A., \& Fankhauser, S. (2011). The green growth narrative: Paradigm shift or just spin? Global Environmental Change, 21, 1157-1159.

Bratman, E. (2015). Passive revolution in the green economy: Activism and the Belo Monte Dam. International Environmental Agreement. doi:10.1007/s10784-014-9268-z.

Brockington, D. (2012). A radically conservative vision? The challenge of UNEP's towards a green economy. Development and Change, 43(1), 409-422.

Clapp, J., \& Dauvergne, P. (2011). Paths to a green world: The political economy of the global environment (2nd ed.). Cambridge MA: The MIT Press.

Coyle, G. (2011). The not-so-green renewable energy: Preventing waste disposal of solar photovoltaic (PV) panels. Golden Gate University Environmental Law Journal, 4, 329-361.

Daly, H. (1995). On Wilfred Beckerman's critique of sustainable development. Environmental Values, 4(1), $49-56$.

Desombre, E. R. (2011). Global environmental governance for a new green economy. Review of Policy Research, 28(5), 467-472.

Dobson, A. (1998). Justice and the environment. Oxford: Oxford University Press Inc.

Ehresman, T., \& Okereke, C. (2015). Environmental justice and conceptions of the green economy. International Environmental Agreements: Politics, Law and Economics. doi:10.1007/s10784-0149265-2.

Ehresman, T., \& Stevis, D. (2011). International environmental justice. In G. Kutting (Ed.), Global environmental politics: Concepts, theories and case studies (pp. 87-104). New York: Routledge.

Evanoff, R. (2011). Bioregionalism and global ethics: A transactional approach to achieving ecological sustainability, social justice, and human well-being. New York: Routledge.

Godoy, E. (2012). The green economy: Boon, or menace? In U. N. DP (Ed.), Green economy in action: Articles and Excerpts that illustrate green economy and sustainable development efforts. New York: United Nations.

Jacobs, M. (1999). Sustainable development as a contested concept. In A. Dobson (Ed.), Fairness and futurity: Essays on environmental sustainability and social justice. Oxford: Oxford University Press.

Jamieson, D. (2007). The heart of environmentalism. In P. C. Pezzullo \& R. D. Sandler (Eds.), Environmental justice and environmentalism: The social justice challenge to the environmental movement. Cambridge: The MIT Press.

Kosoy, N., Brown, P. G., Bosselmann, K., Duraiappah, A., Mackey, B., Martinez-Alier, J., et al. (2012). Pillars for a flourishing Earth: planetary boundaries, economic growth delusion and green economy. Current Opinion in Environmental Sustainability, 4, 74-79.

Langhelle, O. (2000). Sustainable development and social justice: Expanding the Rawlsian framework of global justice. Environmental Values, 9(3), 295-324. 
McKendry, C. \& Janos, N. (2015). Greening the industrial city: Equity, environment and economic growth in Seattle and Chicago. International Environmental Agreements: Politics, Law and Economics. doi:10.1007/s10784-014-9267-0.

Mulvaney, D. (2009). Capital, governance and environmental justice in the clean tech space: Making energy and evaluating risk from solar photovoltaics. Paper presented at the annual meeting of the Association of American Geographers.

Newell, P. (2005). Race, class and the global politics of environmental inequality. Global Environmental Politics, 5(3), 70-94.

Newell, P., \& Mulvaney, D. (2013). The political economy of the 'just transition'. The Geographical Journal, 179(2), 132-140.

Nielsen, T. D. (2014). The role of discourses in governing forests to combat climate change. International Environmental Agreements: Politics, Law and Economics, 14(3), 265-280.

Okereke, C. (2008). Global justice and neoliberal environmental governance: Sustainable development, ethics and international co-operation. London/New York: Routledge.

Okereke, C. (2011). Moral foundations for global environmental and climate justice. Royal Institute of Philosophy Supplement, 69, 117-135.

Paterson, M., Humphreys, D., \& Pettiford, L. (2003). Conceptualizing global environmental governance: From interstate regimes to counter-hegemonic struggles. Global Environmental Politics, 3(2), 1-9.

Rao, N. D. (2014). International and intranational equity in sharing climate change mitigation burdens. International Environmental Agreements: Politics, Law and Economics, 14(2), 129-146.

Redclift, M. (2002). Sustainable development: Exploring the contradictions. London: Routledge.

Sachs, W. (1999). Planet dialectics: Explorations in environment and development. Halifax: Fernwood Publishing.

Stadelman, M., Persson, A., Ratajczak-Juszko, I., \& Michaelowa, A. (2014). Equity and cost-effectiveness of multilateral adaptation finance: are they friends or foes? International Environmental Agreements: Politics, Law and Economics, 14(2), 101-120.

Stevis, D. \& Felli, R. (2015). Global labour unions and just transition to a green economy. International Environmental Agreements. doi:10.1007/s10784-014-9266-1.

Swilling, M., \& Annecke, E. (2012). Just transitions: Explorations of sustainability in an unfair world. New York: United Nations University Press.

UNEP. (2011). Towards a green economy: Pathways to sustainable development and poverty eradication: A synthesis for policy makers. Nairobi: UNEP.

Walker, G., \& Bulkeley, H. (2006). Geographies of environmental justice. Geoforum, 37, 655-659. 